Acta medico-historica Rigensia (1992) I: 339-341

DOI: 10.25143/amhr.1992.I.29

\title{
ОТКРЫТИЕ МЕМОРИАЛЬНОГО МУЗЕЯ ПРОФЕССОРА А. БИЕЗИНЯ
}

Профессор Александр Биезинь (1897-1975) - основоположник детской хирургии в Латвии - вновь вернулся в свой родной хутор «Дилмани» Мадонского района, вол. Саркани. Благодаря усилиям местных тружеников, особенно председателя агрофирмы «Саркани» Я. Рауда, медицинской общественности республики усадьба "Дилмани» начинает новую жизнь, но теперь уже как мемориальный музей профессора А. Биезиня - филиал Музея истории медицины им. П. Страдыня.

27 августа 1989 года в «Дилмани» состоялся День памяти профессора А. Биезиня. Прибыли многие предста-

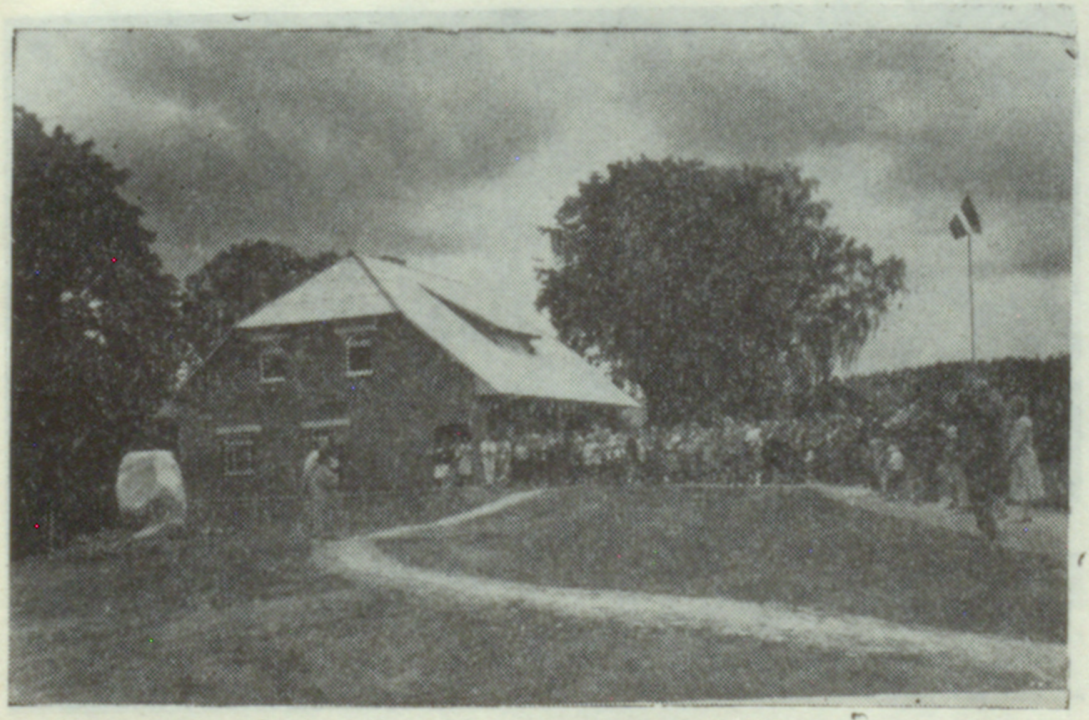

Открытие памятника профессору А. Биезиню на территории музея. Фото: А. Дзение 
вители общественности, коллеги, ученики профессора, видные ученые, бывшие пациенты, земляки. Состоялось открытие памятника А. Биезиню, работы скульптора А. Варпа. Экс-министр здравоохранения Латвийской Республики Э. Платкайс и профессор Я. Гауенс сняли покрывало с памятника, на котором надпись Omne vivum ex vivo (все живое из живого).

С воспоминаниями о профессоре А. Биезине, о его вкладе в медицину и особенно в детскую хирургию выступили Э. Платкайс, профессор Я. Гауенс, главный врач Республиканской детской клинической больницы У. Ламстерс, а также к. м. н. А. Виксна, дочь профессора А. Волрате.

Председатель агрофирмы «Саркани» Я. Рауда торжественно вручил заведующему музеем В. Ферстеру символический ключ от музея, и посетители смогли познакомиться с временной экспозицией, которая отражает жизненный путь профессора А. Бнезиня.

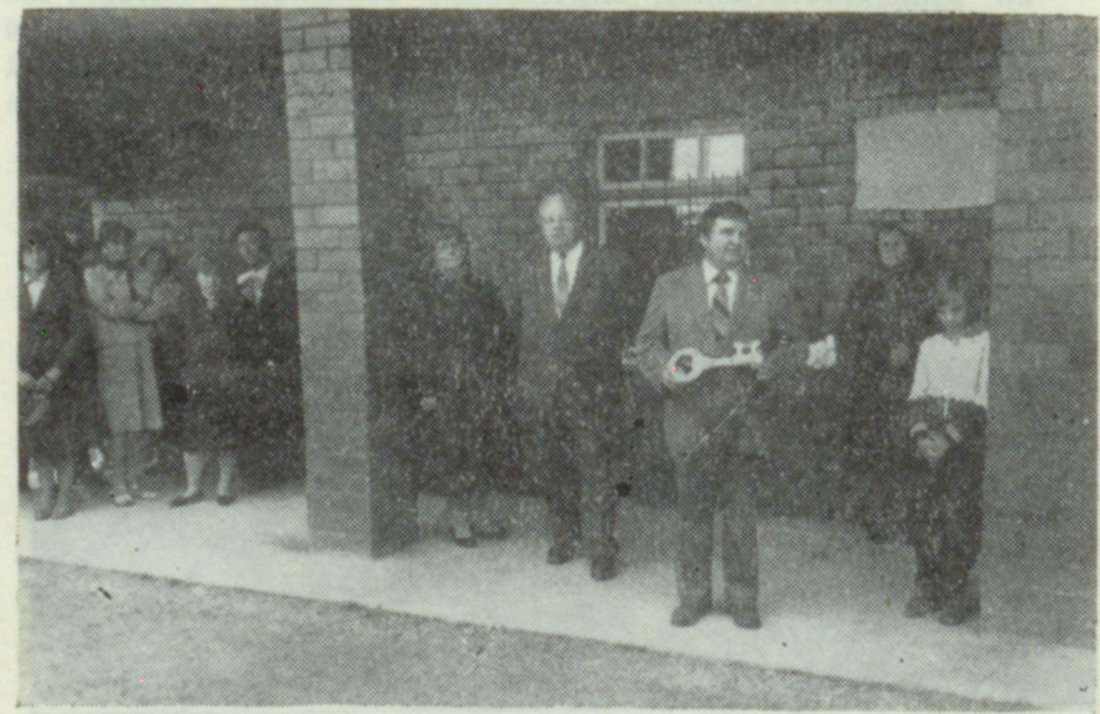

Ключ от музея вручен заведующему В. Ферстеру 
На стене здания музея прикреплена мемориальная бронзовая доска (автор А. Янсонс) с надписью: HIC LOCUS EST, UBI PROFESSOR ALEXANDER BIEZINS PRINCEPS IN RE CHIRURGICA INFANTIUM LATVIAE - DIE XXXI M. AUGUSTI A. MDCCCXCVII NATUS EST.

EIUS DOMUS PATRIA «DILMANI» BENEFICIO FAMILIAE AGRICOLARUM SUI PAGI ET MEDICORUM NOSTRAE REI PUBLICAE RENATA EST

(Это место, где 31 августа 1897 года родился профессор Александр Биезинь - основоположник детской хирургии в Латвии. Его родной хутор «Дилмани» возродился благодаря местным земледельцам и медикам нашей республики).

Работа над совершенствованием экспозиции музея продолжается.

Валдис Ферстерс 